\title{
Could Behavioral Factors Affect Purchaser's Behavior of Real Estate in Jeddah
}

\author{
Tawfik Salah Al-Nahdi ${ }^{1}$, Omar Hassan Ghazzawi ${ }^{1} \&$ Abu Hassan Abu Bakar ${ }^{2}$ \\ ${ }^{1}$ Prince Sultan College for Business, Al-Faisal University, Saudi Arabia \\ ${ }^{2}$ Housing Building and planning school, University Science of Malaysia, Malaysia \\ Correspondence: Tawfik Salah AL-Nahdi, Prince Sultan College for Business, Al-Faisal University, Jeddah, \\ Saudi Arabia. E-mail: t.alnahdi@pscj.edu.sa
}

Received: July 22, 2015

Accepted: August 24, $2015 \quad$ Online Published: September 18, 2015

doi:10.5539/ijbm.v10n10p87

URL: http://dx.doi.org/10.5539/ijbm.v10n10p87

\begin{abstract}
Factors affecting the real estate market are of great importance worldwide. This study will investigate the factors influencing Saudis to purchase real estate. The study examines the effect of Knowledge and learning, Personality, Social class, and family members (Spouse, Children, and Parents) on the intention to purchase real estate. A total of 300 questionnaires were distributed to respondents in Jeddah. Based on 220 questionnaires collected, the results show that knowledge and learning, children's influence, and parents had a positive effect on the intention to purchase real estate, while the personality, social class, and spouse had no effect on the relationship between independents and the customers' intention to purchase real estate among Saudis.
\end{abstract}

Keywords: behavioral real estate, jeddah real estate, purchasing real estate, consumer behavior

\section{Introduction}

Understanding factors that affect this market are found to be very important due to the fact that Utility Theories which have been used to study consumer behavior failed to provide convincing explanations to understand the market (Smith et al., 1992; Gilber \& Nelson, 1998). Globally, few studies on commitment have been conducted but there are increasing assumptions toward studying the market from behavioral point of view (DeLisle, 2012, Graaskamp, 1991; Megbolugbe et al., 1991; Ratcliff, 1965, 1972). From Behavioral point of view insights on consumer purchase behavior were given and also the explanation on what drives consumers to purchase housing (Gilber \& Nelson, 1998; Kokli \& Vida, 2009). Additionally, Robinson (1993) argues that when individuals act in erratic way, and when individuals act in a predictable way, statistical methods are able to discover the laws of economics but from a large number of complicated motives, the economist must leave the task to the psychologist. The driving forces of homebuyers can therefore be understood by the help of Behavioral research (Graaskamp, 1991). More so, there are apparent moves from rational factors to psychological and behavioral factors (Bargh, 2002). It has been argued that the incorporation of information about consumer attitudes, preferences, and perceptions into economic models of housing demand is critical to any reduction of the large margin of unexplained variance in housing consumption behavior (Megbolugbe et al., 1991). Furthermore, many behavioral theories developed in psychology which are applicable to marketing are also relevant to real estate (DeLisle, 2012). The study of real estate can therefore be beneficial by including consumer behavior concepts from sociology, psychology and marketing (Gibler \& Nelson, 1998). Accordingly, many Behavioral Sciences theories that have been applied in marketing are relevant to real estate.

\section{Literature Review}

\subsection{Knowledge and Learning}

Knowledge and learning are said to be very important aspects because, most of consumer ideas, beliefs, and views are acquired by learning and intensive awareness (Al-Jeraisy, 2008). Learning can be defined as all the procedures which involved changing of current pattern of behavior to develop the new ones (Hanna, 1985). Stimuli trigger consumer need recognition. These stimuli will be categorized by holding knowledge to meaning to consumer. The learning of consumer can be influenced by the interaction between the stimulus and existing knowledge (Craik \& Watkins, 1973). Knowledge can also be considered as association between stimulus and response (Al-Jeraisy, 2008). When individual exposes to stimuli and respond to this stimuli Learning is said to 
occur (Al-Jeraisy, 2008).

\subsection{Personality}

Personality has been defined differently by different researchers; Kassarjian (1971) said that personality accounts for consistent patterns of behavior based on enduring psychological characteristics. Razak (2013) defined personality as a dynamic and organized set of systems by a person that uniquely influences his or her cognitions, emotions, interpersonal orientations, motivations and behaviors in various situations. So, Personality is an individual pattern of traits and behaviors that makes him unique, distinctive and different from all others (Gilber \& Nelson, 1998). According to al-Jeraisy (2008) consumer behavior is highly directed by personality of the consumer. Therefore, understanding consumer behavior requires understanding the impact of personality on behavior. In addition personality affects consumer perception and purchase behavior (Al-Jeraisy, 2008). Consumers used to interpret environmental stimuli and then choose what it does not suppose to be termed as personality (Gilber \& Nelson, 1998).

\subsection{Social Class}

Social Class can be defined as the hierarchical division of members the society into classes or levels of prestige, esteem, status and power. These divisions have common traits which usually differentiate each class from other classes. According to this definition, each category has similarities in consumption, utilization, lifestyle and behavior which share similar values, and interest (Rossides, 1990, Gilber \& Nelson, 1998; Al-jerasiy). Gilbert and Kahl (1982) mentioned that previous researchers found that there are variables as most important in determining social class such as the economic variables, income and wealth, personal prestige and many others. According to Gonzalez et al. (2012) useful and utilitarian motives of acquisition and consumption are not the only drivers for consumer behavior but social class also has a significant effect on consumer behavior.

\subsection{Family}

Al-Jeraisy (2008) observes that family is important to consumption; according to him the family as unit considered as individual but it has more variety needs and wants and it buys numerous numbers of durables. Al-Jeraisy (2008) further adds that understanding family consumption behavior is important for marketers in order to satisfy the wants and needs of families and design suitable marketing plans for their products and service.

\subsection{The Spouse's Influence}

The spouse more especially husband and wife play several roles in influencing purchasing, depending on the type of product, even though the wife will not make the final decision. With respect to durables, the husband and wife usually share their decisions of purchasing them, sometimes bearing in mind their children's requirements too. Family, from a social viewpoint, interacts as a functional unit (Al-Jeraisy, 2008). In traditional societies, husbands play the major role in deciding about purchasing. While in modern societies the husband still has the most say when purchasing, the spouse also has increasingly significant influence, especially when it relates to purchasing with high risk and long financial commitment (Qualls, 1984). In Saudi society, the wife plays a vital role in defining the family's basic needs and wants. In addition, due to the higher level of education achieved by Saudi females and with the resultant employment, they were able to participate in decisions involving high risk products such as housing and the like.

\subsection{The Child's Influence}

According to Al-Jeraisy, (2008) prior to the seventies, Saudi society was mostly a traditional society after which the society started moving towards a "modern" society where children were provided with good education, knowledge, and more ability to express their wants and needs and other personal interest. Because their wants and needs have changed (as compared to those of the older generations), the incorporation of children and the study of their influence in purchasing, has become necessary and important factor in understanding the Saudi family's house-purchasing behavior.

Elsewhere, studies from Thailand have revealed that children have important role to play in purchasing housing; in fact, they played the most influential role (Sangkakoon et al., 2013). During the purchasing process, Sangkakoon et al. (2013) found that the influence of children happens in many stages depending on the importance of the products or services. Levy, et al, states that although parents try to share decision-making among the family members, ultimately parents are the final judge (Levy \& Lee, 2004).

\subsection{The Parents' Influence}

Generally, the lives of children were influenced by their parents and this influence carries on until the children 
create their own families (Levy \& Lee, 2004). In Saudi society there is still a very good and strong relationship between parents and their children. The Saudi parent plays the pivotal role in shaping consumption behavior in his/ her society. Parents pursue and keep their influence on their family members even with married couples with children (Al-Jeraisy, 2008). Al-Jeraisy (2008) conducted a study and found that in Saudi society the father has influence on his sons with regard to purchasing behavior.

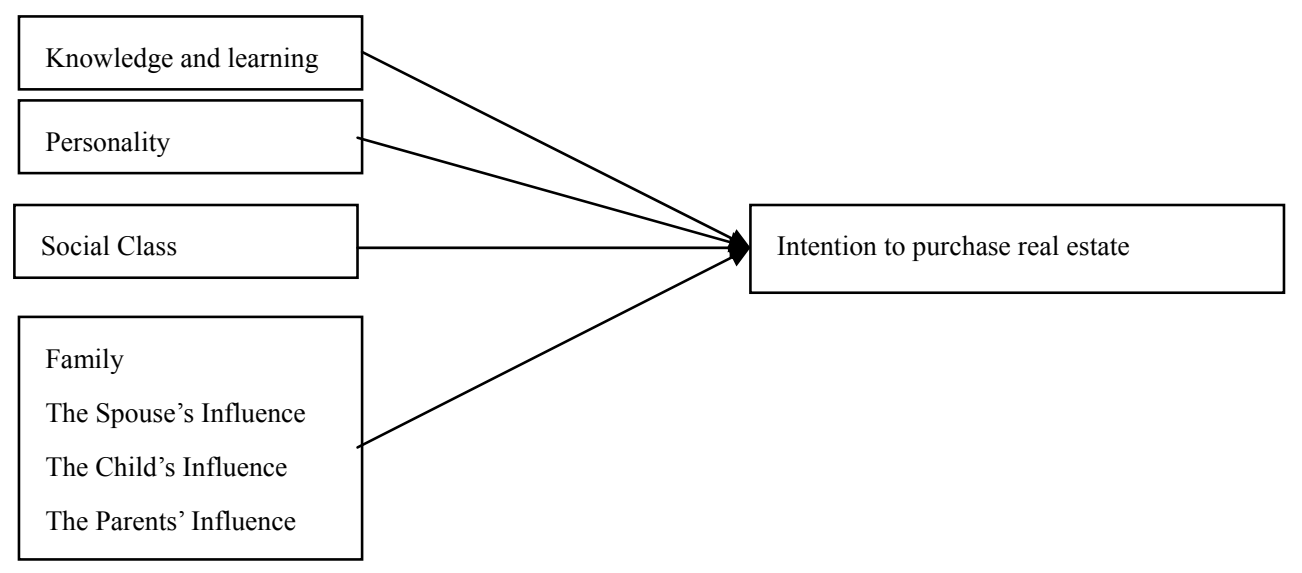

Figure 1. The effect of independent variables on dependent variable

\section{Methodology}

This study collected data through a survey distributed in Jeddah using a self-administrated questionnaire. The questions were adapted from various researches, namely Numraktrakul et al. (2012); Al-Nahdi (2008, 2009, 2014, \& 2015) and Razak et al. (2013). The questionnaire consists of two main sections. The first section asks about the respondent's characteristics. The second section covers Knowledge and learning, Personality, Social class, and family members (Spouse, Children, and Parents) on the intention to purchase real estate. The five-point Likert Scale was used to assess variables (ranging from 1, Strongly Disagree to 5, Strongly Agree). The Population for this study is people living in Jeddah who are above 18 years old. Random sampling technique was used in selecting the sample, the data collection was conducted by using a questionnaire which has been adapted from various researches and distributed directly to the respondents. Factor analysis and reliability were used to test the goodness of the measures. Factor analysis is a test of how well an instrument measures the concept, whereas reliability is a test of how consistently a measuring instrument measures the concept (Sekaran \& Bougie, 2010). In this study, the statistical tool SPSS (Statistical Package for Social Science) version 21.0 was applied to analyze the data profile and also the hypotheses testing. Descriptive Analysis was used to analyze the demographic information of respondents. In order to test the goodness of measure analysis, factor analysis and reliability analysis were used (Hair et al., 1998, 2006; Sekaran, 2003). This was to ensure that the data used to test the hypotheses are both valid and reliable. Factor Analysis was conducted based on Hair et al., $(1998,2006)$ the Varimax rotation method. The Kaiser- Meyer-Olkin (KMO) measure of sampling adequacy Bartlett's test of sphericity and anti-image correlation were included in the factor analysis in order to verify the assumptions undertaken by the factor analysis. Cronbach's alpha was used to analyze the reliability of the instruments. For hypothesis testing and investigating the relationship between the independent and dependent variables Regression Analysis was employed.

\subsection{Response Rate}

A total of 300 sets of questionnaires were distributed to respondents in Jeddah. Out of the total of questionnaires distributed, Only 220 sets of the questionnaires were usable which represents a rate of $73 \%$. 


\subsection{Analyses and Results}

Table 1. Profile of respondents

\begin{tabular}{|c|c|c|c|}
\hline Respondent's profile & Category & Frequency & Percentage \\
\hline \multirow[t]{4}{*}{ Age } & $18-25$ & 27 & 12.3 \\
\hline & $26-33$ & 54 & 24.5 \\
\hline & $34-40$ & 74 & 33.6 \\
\hline & Above 40 & 65 & 29.5 \\
\hline \multirow[t]{2}{*}{ Gender } & Male & 185 & 84.1 \\
\hline & Female & 35 & 15.9 \\
\hline \multirow[t]{2}{*}{ Marital status } & Single & 45 & 20.5 \\
\hline & Married & 175 & 79.5 \\
\hline \multirow[t]{4}{*}{ Family members } & 2 & 39 & 17.7 \\
\hline & $3-4$ & 82 & 37.3 \\
\hline & $5-6$ & 59 & 26.8 \\
\hline & More than 6 & 40 & 18.2 \\
\hline \multirow[t]{2}{*}{ Nationality } & Saudi & 175 & 79.5 \\
\hline & Non Saudi & 45 & 20.5 \\
\hline \multirow[t]{6}{*}{ Education } & Primary level & 1 & .5 \\
\hline & Intermediate level & 6 & 2.7 \\
\hline & Secondary level & 36 & 16.4 \\
\hline & Diploma/Degree & 40 & 18.2 \\
\hline & Degree & 103 & 46.8 \\
\hline & Postgraduate & 34 & 15.5 \\
\hline \multirow[t]{4}{*}{$J o b$} & Retired & 14 & 6.4 \\
\hline & Private sector & 134 & 60.9 \\
\hline & Government & 48 & 21.8 \\
\hline & Other & 24 & 10.9 \\
\hline \multirow[t]{4}{*}{ Income } & Below SR 10,000 & 108 & 49.1 \\
\hline & SR 10,001 to SR 20,000 & 73 & 33.2 \\
\hline & SR 20,001 to SR 50,000 & 33 & 15.0 \\
\hline & Above SR 50,001 & 6 & 2.7 \\
\hline \multirow[t]{2}{*}{ Own housing } & Yes & 113 & 51.4 \\
\hline & No & 107 & 48.6 \\
\hline
\end{tabular}

\subsection{Factor Analysis}

Factor analysis was used to ensure that the number of items can be reduced to the number of concepts that were initially hypothesized (Hair et al., 1998). Minimum acceptable value for KMO is 0.50 for Bartlett's test of sphericity to be significant. For the Eigen-value, the value should be 1 or greater. The cut-off point for significant factor loading should be at least 0.35 on one factor.

Table 2 summarizes factor loadings and cross-factor loadings for independent variables that were extracted from the rotated component matrix. In this study, the variables include Knowledge and learning, Personality, Social class, and family members Spouse, Children, and Parents and intention to purchase real estate; Factor analysis was done on all items measuring the independent and dependent variables.

\subsection{Reliability Analysis}

Reliability Analysis was conducted to ensure the consistency or stability of the items (Sekeran, 2003). The Cronbach's alpha test was used to analyze the reliability of the instrument. In this section all variables, namely Knowledge and learning, Personality, Social class, and family members Spouse, Children, and Parents and intention to purchase real estate, are included in the reliability analysis. Table 2 shows the values of Cronbach's alpha for all the variables.

\subsection{Descriptive Analysis}

Descriptive analysis for variables such as Knowledge and learning, Personality, Social class, and family members Spouse, Children, and Parents and dependents (in this case, Intention) is presented in Table 2. 
Table 2. Results of the factor analysis, reliability and descriptive

\begin{tabular}{|c|c|c|c|c|c|c|}
\hline Variables & Loadings & Eigenvalue & Variance & Reliability & Mean & $\begin{array}{l}\text { Standard } \\
\text { deviation }\end{array}$ \\
\hline Knowledge & & 4.14 & 19.72 & .796 & 3.62 & .93 \\
\hline $\begin{array}{l}\text { Knowledge and learning would } \\
\text { determine my intention to purchase } \\
\text { a property }\end{array}$ & .774 & & & & & \\
\hline $\begin{array}{l}\text { Knowledge about property describes } \\
\text { the value of the property standard }\end{array}$ & .828 & & & & & \\
\hline $\begin{array}{l}\text { Knowledge about property describes } \\
\text { the value of the property standard }\end{array}$ & .733 & & & & & \\
\hline $\begin{array}{l}\text { Knowledge about the property is } \\
\text { making decision to purchase property }\end{array}$ & .731 & & & & & \\
\hline Personality & & 3.58 & 17.05 & .869 & 3.7 .72 & 1.175 \\
\hline $\begin{array}{l}\text { Living in Jeddah is consistent with } \\
\text { how I see myself }\end{array}$ & .897 & & & & & \\
\hline $\begin{array}{l}\text { I am quite similar to the personality } \\
\text { of Jeddah }\end{array}$ & .906 & & & & & \\
\hline Social class & & 2.05 & 9.76 & .652 & 3.19 & .87 \\
\hline $\begin{array}{l}\text { Social class would determine my } \\
\text { intention to purchase a property }\end{array}$ & .664 & & & & & \\
\hline $\begin{array}{l}\text { It is important for me to purchase } \\
\text { high quality, expensive property }\end{array}$ & .821 & & & & & \\
\hline $\begin{array}{l}\text { I would like to seek for property that } \\
\text { can greatly express my individuality }\end{array}$ & .443 & & & & & \\
\hline $\begin{array}{l}\text { The higher the property price, the } \\
\text { higher the quality }\end{array}$ & .703 & & & & & \\
\hline Spouse influence & & 1.77 & 8.45 & .730 & 3.57 & .932 \\
\hline $\begin{array}{l}\text { Spouse influences me when selecting } \\
\text { the design for the housing }\end{array}$ & .737 & & & & & \\
\hline $\begin{array}{l}\text { Spouse influences me when selecting } \\
\text { the living space of the housing }\end{array}$ & .889 & & & & & \\
\hline $\begin{array}{l}\text { Spouse influences me when selecting } \\
\text { the location of the housing }\end{array}$ & .694 & & & & & \\
\hline $\begin{array}{l}\text { Children influence } \\
\text { My children would want me to } \\
\text { purchase housing with play area for } \\
\text { children }\end{array}$ & .840 & 1.46 & 6.98 & .810 & 3.30 & 1.08 \\
\hline $\begin{array}{l}\text { My children would want me to } \\
\text { purchase housing with private area } \\
\text { for children } \\
\text { My children would want me to } \\
\text { purchase housing with a good } \\
\text { environment for children }\end{array}$ & .889 & & & & & \\
\hline Parent influence & & 1.33 & 6.36 & .864 & 2.65 & .982 \\
\hline $\begin{array}{l}\text { My parents think that I should plan to } \\
\text { pay the instalment on my housing }\end{array}$ & .493 & & & & & \\
\hline $\begin{array}{l}\text { My parents are influential in my } \\
\text { decision to purchase housing }\end{array}$ & .972 & & & & & \\
\hline $\begin{array}{l}\text { My parents tend to support a down- } \\
\text { payment when I purchase housing }\end{array}$ & .983 & & & & & \\
\hline $\begin{array}{l}\text { My parents tend to support monthly } \\
\text { installment when I purchasing } \\
\text { housing }\end{array}$ & .846 & & & & & \\
\hline $\begin{array}{l}\text { My parents tend to give me a loan for } \\
\text { purchasing my housing }\end{array}$ & .833 & & & & & \\
\hline
\end{tabular}




\begin{tabular}{|c|c|c|c|c|c|c|}
\hline Intention & & 3.656 & 52.23 & 0840 & 3.47 & 0.92 \\
\hline $\begin{array}{l}\text { I will continue to purchase housing in } \\
\text { the future }\end{array}$ & .606 & & & & & \\
\hline $\begin{array}{l}\text { I intend to purchase housing } \\
\text { frequently in the future. }\end{array}$ & .808 & & & & & \\
\hline I plan to purchase housing. & .761 & & & & & \\
\hline I will try to purchase housing. & .803 & & & & & \\
\hline I want to purchase housing. & .807 & & & & & \\
\hline $\begin{array}{l}\text { I have got a plan/ strategy to purchase } \\
\text { new housing. }\end{array}$ & .481 & & & & & \\
\hline $\begin{array}{l}\text { I will make serious efforts to } \\
\text { purchase housing }\end{array}$ & .728 & & & & & \\
\hline
\end{tabular}

\subsection{Testing the Hypotheses}

The regression analyses were performed to determine the relationship between the independent variables and dependent variable.

The results show that $R$ square $=13 \%$; this means that about $13 \%$ of the variation in the dependent variable can be explained by the independent variables jointly. $\mathrm{F}$ value $=5.488$, and $\mathrm{p}=000<.01$ which is very significant, implying that the model is adequate. The Durbin-Watson Test $\mathrm{D}=1.543$. Detailed results of the regression analyses are shown in table below.

Table 3. Results of regression analysis

\begin{tabular}{lc}
\hline Variable & STANDARDIZED COEFFICIENTS BETA \\
\hline Knowledge and learning & $0.231^{* * *}$ \\
Personality & 0.009 \\
Social class & -0.055 \\
Spouse Influence & 0.026 \\
Children influence & $0.231^{* * *}$ \\
Parent Influence & $0.152^{*}$ \\
R2 & 0.134 \\
ADJUSTED R2 & 0.109 \\
F & 5.488 \\
SIGNIFICANT & 0.000 \\
DURBIN-WATSON TEST & 1.543 \\
\hline
\end{tabular}

Note. ${ }^{*} \mathrm{p} \leq .05 * * \mathrm{p} \leq .01 * * * \mathrm{p} \leq .001$.

Ho1 The more positive the Knowledge and learning, the greater is the consumers' purchase intention of real estate in Saudi Arabia.

Table 3 shows the results between Knowledge and learning and intention to purchase real estate. Based on the results, Knowledge and learning was significant at $* * * p<.001$ with Standardized Coefficients Beta $=0.231$, having a positive effect on Intention. Thus, Hol is accepted.

Ho2 The more positive Personality, the greater is the consumers' purchase intention of real estate in Saudi Arabia.

Table 3 shows the results of the degree of effect of Personality toward intention to purchase real estate. Based on the results, Personality was not significant $p>.00$ with Standardized Coefficients Beta $=0.009$ and had no effect on intention to purchase real estate. Thus, Ho2 is rejected.

Ho3 The more positive Social class, the greater is the consumers' purchase intention of real estate in Saudi Arabia.

Table 3 shows the results of the degree of effect of Social class toward intention to purchase real estate. Based on the results, Social class was not significant $p>.00$ with Standardized Coefficients Beta $=-0.055$ and had no effect on intention to purchase real estate. Thus, Ho3 is rejected. 
Ho4 The more positive the Spouse's influence, the greater is the consumers' purchase intention of real estate in Saudi Arabia.

Table 3 shows the results of the degree of effect of the Spouse's influence toward intention to purchase real estate. Based on the results, the Spouse's influence was not significant $p>.00$ with Standardized Coefficients Beta $=0.026$ and had no effect on intention to purchase real estate. Thus, Ho4 is accepted.

Ho5 The more positive children's influence, the greater is the consumers' purchase intention of real estate in Saudi Arabia.

Table 3 shows the results of the degree of effect of children's influence toward intention to purchase real estate. Based on the results, children's influence was significant at $p<.01$ with Standardized Coefficients Beta $=0.231$ and had a positive effect on intention to purchase real estate. Thus, H5 is supported.

Ho6 The more positive parents' influence, the greater is the consumers' purchase intention of real estate in Saudi Arabia.

Table 3 shows the results of the degree of effect of parents' influence toward intention to purchase real estate. Based on the results, parents' influence was significant at $p<.05$ with Standardized Coefficients Beta $=0.152$ and had a positive effect on intention to purchase real estate. Thus, Ho6 is accepted.

\section{Conclusion and Recommendation}

\subsection{Conclusion}

Based on the findings of this study, it can be concluded that knowledge and learning, children's influence, and parents had a positive effect on the intention to purchase real estate, while the personality, social class, and spouse had not. The study has illustrated the ability of the Gilber and Nelson Model (1998) to explain the intention to purchase real estate. It was shown that the intention to purchase real estate was influenced by knowledge and learning, children's influence, and parents, while the personality, social class, and spouse were not, with the knowledge and learning and children's influence being the most influential.

The study has shown that knowledge and learning, children's influence, and parents are accepted in this study. In conclusion, it is assumed that the outcomes of this study will have contributed some valuable information for researchers, customers, marketers and real estate owners. It is expected that the result of the survey will provide clear information on the intention to purchase real estate, and which variables actually affect this intention. This study provided evidence and information as to what really influences the intention to purchase property. The study can thus serve as a future reference on the study of real estate.

Admittedly, there are some limitations which must be given due attention.

\subsection{Limitations}

Several limitations have been identified in this study. Since this study was conducted in Jeddah only it may not give a general picture to all customers in Saudi Arabia. Thus, the result obtained may not accurately reflect the actual customers' intention to purchase real estate all over Saudi Arabia. As a result of this, the findings of this study cannot be generalized to customers' intention to purchase real estate all over Saudi Arabia and the world at large.

\subsection{Future Research}

Including more variables, i.e. other than the ones mentioned in this research, may explain behavioral intention even more succinctly. Additional research in many different geographical areas in the country can be conducted so as to generalize the findings. And, finally, if characteristics of respondents in the surveys could be included in future research; it might present a clearer view of what motivates purchasers of real estate.

\section{References}

Al-Ghadeer, H., \& Al-Saed, R. (n. d.). Consumer behavior.

Al-Jeraisy, K. I. (2008). Consumer behavior: An analytical study of the Saudi family's purchase decisions. Riyadh: distributed by Al-Jeraisy Establishment.

Al-Nahdi, M. T. S. M., Ismail, I., Haron, H., \& Islam, M. A. (2009). Intention to patronage halal restaurants among Malaysian Muslims-an issue of halal perception. Paper presented at the Global Business Summit Conference.

Al-Nahdi, T. S., \& Abu Bakar, A., (2015). Motives of Saudis to purchase Real Estate in Saudi Arabia. J. Appl. Sci. \& Agric., 10(1), 41-52. 
Al-Nahdi, T. S. (2014). Factors Influencing the Intention to Purchase Real Estate in Saudi Arabia Role of Location. J. Appl. Sci. \& Agric., 9(18), 32-42.

Al-Nahdi, T. S. (2015). Factors Influencing the Intention to Purchase Real Estate in Saudi Arabia. Role of Public service. J. Appl. Sci. \& Agric., 10(2), 1-11.

Al-Nahdi, T. S. (2015). Purchasing housing in Saudi Arabia a behavioral study. J. Appl. Sci. \& Agric., 10(2), 12-21.

Al-Nahdi, T. S. M., \& Islam, A. (2011). Factors Influencing Malaysian Muslims to Patronage Halal Restaurants-Ambience As a Mediator. IBA Business Review, 6(2).

Al-Nahdi, T. S., \& Abu Bakar, A. (2014). Factors Influencing Purchase Intention of Real Estate in Saudi Arabia. J. Appl. Sci. \& Agric., 9(17), 27-39.

Al-Nahdi, T. S., \& Abu Bakar, A. (2015). The Moderating Effect of Public Service on Intention to purchase Real Estate in Saudi Arabia. J. Appl. Sci. \& Agric., 10(1), 29-40.

Al-Nahdi, T. S., Habib, S. A., \& Albdour, A. A. (2015). Factors Influencing the Intention to Purchase Real Estate in Saudi Arabia: Moderating Effect of Demographic Citizenship. International Journal of Business and Management, 10(4), 35. http://dx.doi.org/10.55339.ijbm.v10n4p35

Bargh, J. A. (2002). Losing consciousness: Automatic influences on consumer judgment, behavior, and motivation. Journal of Consumer Research, 29(2), 280-285. http://dx.doi.org/10.1086/341577

Blanco-González, A., Martín-Armario, E., \& Mercado-Idoeta, C. (2012). Collectors' Buying Behavior: A Model Based On Attitudes and Market Heterogeneity. American International Journal of Contemporary Research, 2(6), 164-175.

Craik, F. I. M., \& Michael, J. W. (1973). The Role of Rehearsal in Short-Term Memory. Journal of Verbal Learning and Verbal Behavior, 599-607. http://dx.doi.org/10.1016/S0022-5371(73)80039-8

DeLisle, J. R. (2012). Lessons (To Be) Learned. The Appraisal Journal. Appraisal Institute, Chicago, Illinois

Gibler, K. M., \& Nelson, S. L. (2003). Consumer behavior applications to real estate education. Journal of Real Estate Practice and Education, 6(1), 63-89.

Gilbert, D., \& Joseph, A. K. (1982). The American Class Structure (3rd ed.). Wadsworth, Inc.

Gilbert, D., \& Kahl, A. (1982). The American Class Structure (3rd ed.). Wadsworth, Inc.

Graaskamp, J. A., \& Jarchow, S. P. (1991). Graaskamp on real estate. ULI-the Urban Land Institute.

Hair, J. F., Anderson, R. E., Tatham, R. L., \& Black, W. C. (1998). Multvariate data analysis (5th ed.). New Jersey: New Jersey.

Hair, J. F., Black, W. C., Babin, B. J., Anderson, R. E., \& Tatham, R. L. (2006). Multivariate data analysis (Vol. 6). Upper Saddle River, NJ: Pearson Prentice Hall.

Hanna, N. (1985). Marketing Principles. Riyadh: Marikh Publishing.

Kassarjian, H. (n.d.). Personality and Consumer Behavior. Journal of Marketing Research.

Kokli, C. M. K., \& Vida, I. (2009). A Strategic Household Purchase: Consumer House Buying Behavior. Managing Global Transitions, 7(1), 75-96.

Levy, D., \& Lee, C. K. C. (2004). The influence of family members on housing purchase decisions. Journal of Property Investment \& Finance, 22(4), 320-338. http://dx.doi.org/10.1108/14635780410550885

Megbolugbe, I. A. M., \& Schwartz, M. (1991). The Economic Theory of Housing Demand: A Critical Review. Journal of Real Estate Research, American Real Estate Society, 6(3), 381-393.

Numraktrakul, P., Ngarmyarn, A., \& Panichpathom, S. (2012). Factors Affecting Green Housing Purchase. In 17th International Business Research Conference. Toronto, Canada.

Qualls, W. J. (1984). Sex Roles, Husband-Wife Influence, and Family Decision Behavior. Advances in Consumer Research, 11(1), 270-275.

Ratcliff, R. (1965). Modern Real Estate Valuation. Madison, WI: Democratic Press

Ratcliff, R. (1972). Valuation for Real Esatate Decisions. Santa Cruz: Democratic Press.

Razak, M. I., Ibrahim, R., Abdullah, N., Osman, I., \& Alias, Z., (2013). Purchasing Intention towards Real Estate Development in Setia Alam, Shah Alam: Evidence from Malaysia. International Journal of Business, 
Humanities and Technology, 3(6).

Robinson, J. (1993). The Economics of Imperfect Competition, Introduction and Chapter 15 reprinted. In Needy, Charles W. (Ed.), Classics of Economics. Oak Park: Moore Publishing Company, Inc.

Rossides, D. W. (1990). Social Stratification. Englewood Cliffs, NJ: Prentice-Hall, 1990.

Sangkakoon, P. (2014). The influence of group references in home purchase intention in Thailand. 21st Annual European Real Estate Society Conference in Bucharest. Retrieved from http://eres.scix.net/cgi-bin/works/Show?eres2014_191

Sarjian, H. (1971). Personality and Consumer Behavior. Journal of Marketing Research, 8, 409-418.

Sekaran, U., \& Bougie, R. (2010). Research methods for business: A skill building approach. Wiley.

\section{Copyrights}

Copyright for this article is retained by the author(s), with first publication rights granted to the journal.

This is an open-access article distributed under the terms and conditions of the Creative Commons Attribution license (http://creativecommons.org/licenses/by/3.0/). 